\title{
Interactive effects of grazing and burning on wind- and water-driven sediment fluxes: rangeland management implications
}

\author{
Jason P. Field, ${ }^{1,5}$ David D. Breshears, ${ }^{1,2}$ Jeffrey J. Whicker, ${ }^{3}$ and Chris B. Zou ${ }^{4}$ \\ ${ }^{1}$ School of Natural Resources and the Environment, University of Arizona, Tucson, Arizona 85721 USA \\ ${ }^{2}$ Department of Ecology and Evolutionary Biology, University of Arizona, Tucson, Arizona 85721 USA \\ ${ }^{3}$ Environmental Programs, Los Alamos National Laboratory, Los Alamos, New Mexico 87545 USA \\ ${ }^{4}$ Department of Natural Resource Ecology and Management, Oklahoma State University, Stillwater, Oklahoma 74078 USA
}

\begin{abstract}
Rangelands are globally extensive, provide fundamental ecosystem services, and are tightly coupled human-ecological systems. Rangeland sustainability depends largely on the implementation and utilization of various grazing and burning practices optimized to protect against soil erosion and transport. In many cases, however, land management practices lead to increased soil erosion and sediment fluxes for reasons that are poorly understood. Because few studies have directly measured both wind and water erosion and transport, an assessment of how they may differentially respond to grazing and burning practices is lacking. Here, we report simultaneous, co-located estimates of wind- and water-driven sediment transport in a semiarid grassland in Arizona, USA, over three years for four land management treatments: control, grazed, burned, and burned + grazed. For all treatments and most years, annual rates of wind-driven sediment transport exceeded that of water due to a combination of ongoing small but nontrivial wind events and larger, less frequent, wind events that generally preceded the monsoon season. Sediment fluxes by both wind and water differed consistently by treatment: burned + grazed $>$ burned $\gg$ grazed $\geq$ control, with effects immediately apparent after burning but delayed after grazing until the following growing season. Notably, the wind : water sediment transport ratio decreased following burning but increased following grazing. Our results show how rangeland practices disproportionally alter sediment fluxes driven by wind and water, differences that could potentially help explain divergence between rangeland sustainability and degradation.
\end{abstract}

Key words: aeolian transport; erosion; fire; fluvial transport; grassland; livestock; resource redistribution; sediment transport; soil.

\section{INTRODUCTION}

Rangelands are the most abundant type of humanmanaged ecosystems in the world and account for a large fraction of the terrestrial land surface (Holechek et al. 2001). Rangelands play a major role in supporting human populations and are estimated to provide $>\$ 900$ billion worth of ecosystems services annually, such as food production, water regulation, erosion control, and recreation (Costanza et al. 1997, Millennium Ecosystem Assessment 2005, Havstad et al. 2007, Greiner et al. 2009). Long-term rangeland sustainability depends in large part on minimizing soil erosion and sediment fluxes and their potential adverse impacts on soil quality and fertility. Erosion by wind and water has long been recognized as a serious problem on rangelands (Sampson and Weyl 1918, Bennett and Chapline 1928, Weaver and Noll 1935), and is considered to be the most severe consequence of rangeland mismanagement or overgrazing (Holechek et al. 2001). Many natural and

Manuscript received 21 December 2009; accepted 25 February 2010; final version received 12 April 2010. Corresponding Editor: J. Belnap.

${ }^{5}$ E-mail: jpfield@email.arizona.edu human-managed ecosystems are adversely impacted by soil erosion and wind- and water-driven sediment fluxes. The effects are often widespread and long lasting because soil erosion and sediment fluxes can reduce the productivity of the land and ultimately lead to a reduction in the diversity of plants, animals, and microbes (Larson et al. 1983, Pimentel and Kounang 1998, Lal et al. 2003). Soil formation on rangelands is a slow process, often taking thousands of years to form a few inches of topsoil, which under mismanaged or overgrazed systems can be lost on the order of months to years due to accelerated rates of wind and water erosion (Stevens and Walker 1970, Dregne 1983, Trimble and Mendel 1995, Pillans 1997, Chartier et al. 2009). Because of the slow rate at which soils form and their underlying importance in maintaining land productivity, a critical component of any range management plan is to maintain adequate vegetation cover to protect the soil surface from wind and water erosion and transport (Thurow and Taylor 1999, Emmerich and Heitschmidt 2002).

Management for rangeland sustainability centers primarily on the implementation of various grazing and burning practices, which control to a large extent 
the amount and distribution of vegetation cover. Vegetation cover can have a large influence on the absolute and relative magnitudes of wind and water erosion and transport, and is perhaps the most important factor influencing both types of erosion (Breshears et al. 2003, Visser et al. 2004, Field et al. $2009 a$ ). For example, water is thought to be the dominant force controlling soil erosion and resource redistribution in semiarid systems characterized by banded vegetation (i.e., dense vegetation patches that form bands or strips perpendicular to the slope within the low plant cover matrix). In contrast, wind is thought to be the dominant force controlling erosion and redistribution in semiarid systems characterized by spotted vegetation (i.e., dense vegetation patches that form irregular circular shapes from 1 to $100 \mathrm{~m}$ in diameter within the low plant cover matrix) (Aguiar and Sala 1999). The redistribution of sediment and other materials, such as nutrients and organic matter, by both wind and water can greatly alter the surface characteristics of rangeland soils, which in turn can modify certain hydrological processes, including water infiltration rates, water storage capacity, runoff/run-on patterns, and erosion rates (Rostagno et al. 1988, Parsons et al. 1992, Bochet et al. 2000, Nash et al. 2004). Sediment fluxes driven by both wind and water can redistribute essential resources in these ecosystems, such as nutrientrich sediment, organic matter, and seeds (Aguiar and Sala 1999). Unlike wind, however, water-driven sediment fluxes may also result in the redistribution of surface water, and is therefore particularly important in arid and semiarid rangelands, where soil water availability is often the most critical factor controlling plant productivity and reproduction (Noy-Meir 1973, Dunkerley 2002, Wilcox et al. 2003). Interactions between wind- and water-driven sediment fluxes and biotic processes can lead to increased resource heterogeneity on rangelands and can have important consequences on the structure and composition of vegetation within these human-managed ecosystems (Schlesinger et al. 1990).

Rapid shifts in the amount and distribution of vegetation cover can ultimately result in the degradation of rangelands and other ecosystems that are susceptible to soil erosion and wind- and water-driven sediment fluxes (Turnbull et al. 2008, Breshears et al. 2009, Okin et al. 2009). Range management practices that involve livestock grazing or prescribed burning usually result in at least a temporary reduction in the amount of protective vegetation cover, and in the case of grazing, some amount of surface disturbance, both of which can greatly increase soil susceptibility to the erosive forces of wind and water (Belnap 1995, Whicker et al. 2002, Ravi et al. 2007, Neff et al. 2008, Belnap et al. 2009). Surface disturbances, such as a reduction in the extent or quality of biological soil crust following grazing or fire-induced soil water repellency in soils, can result in a decrease in the erosion threshold for both wind- and water-driven sediment transport (Belnap 1995, Nash et al. 2004, Ravi et al. 2006). Fire is an important process in rangeland ecosystems, and its ecological and environmental consequences are related to several factors including the timing, severity, and frequency of fire (DeBano et al. 1998). Fire can affect nutrient loss pathways such as volatilization, ash convection, wind erosion, runoff, and leaching of fire-released nutrients (Schoch and Binkley 1986). In addition, feedbacks between wind- and waterdriven sediment transport following fire can promote the redistribution of soil resources from vegetative patches to nutrient-depleted interspaces and result in more homogeneous distribution of vegetation and soil resources (Ravi et al. 2009). Because of its effectiveness, prescribed fire is frequently used as a management tool on rangelands to reduce fuel loads, control exotic and competitive understory species, facilitate seeding of native plant species, and increase seedling growth and survival (DeBano et al. 1998).

Despite the widely documented adverse ecological effects of soil erosion and sediment transport on rangelands (Thurow and Taylor 1999, Holechek et al. 2001, Emmerich and Heitschmidt 2002), essentially no studies have reported co-located field measurements of wind and water erosion and transport, particularly following disturbance (Visser et al. 2004). Assessments of how both types of sediment fluxes may differentially respond to disturbances are largely lacking, precluding to a large part our understanding of the dynamic nature of wind and water erosion and their potential interactions and consequences. Accurate assessment of wind- and water-driven sediment transport together is critical to managing the health and sustainability of rangelands (Weltz et al. 2003) because both processes can contribute substantially to total erosion rates in most arid and semiarid ecosystems (Schumm 1965, Breshears et al. 2003, Bullard and McTainsh 2003, Visser et al. 2004). Potential interactions between aeolian (wind-driven) and fluvial processes at the landscape scale can have a large influence on sediment fluxes into and out of dryland ecosystems (Field et al. 2009a). For example, fluvial sediment from lake beds, riverbeds, and flood plains can be transported long distances by wind and subsequently deposited as aeolian material, at which point either wind or water can further redistribute the sediment, thus increasing the potential for interactions between aeolian and fluvial processes (Bullard and Livingstone 2002, Bullard and McTainsh 2003).

Here we evaluate soil erosion and sediment fluxes driven by both wind and water under natural field conditions for disturbed and relatively undisturbed rangelands using a recently developed approach for comparing aeolian vs. fluvial sediment transport (Breshears et al. 2003). Sediment transport driven by aeolian and fluvial processes can be compared directly to each other by measuring the mass of sediment passing through a unit length that is perpendicular to the erosional vector for each force (Breshears et al. 2003). In 
general, vertical dust flux (i.e., soil erosion) is widely accepted as a function of saltation flux or horizontal sediment transport (Gillette 1977, Shao et al. 1996, Gillette et al. 1997, Alfaro and Gomes 2001), although in some cases horizontal aeolian sediment transport measured in this way may not be a major factor controlling suspended dust emissions (Zobeck et al. 2003). Fluvial sediment transport has also been shown to be related to erosion rates under a variety of field conditions (Moss and Walker 1978). In this study we evaluate soil erosion and sediment transport in a semiarid grassland because these systems represent a large fraction of the earth's land surface and are inherently susceptible to both types of erosion due to the patchy distribution of vegetation cover characteristic of these systems (Belnap 1995, Aguiar and Sala 1999, Stout 2001). Although the environmental and economic importance of wind and water erosion has been well documented in human-managed ecosystems, most studies consider only one erosional process (Field et al. 2009a). Critical knowledge gaps, therefore, remain about their relative magnitudes and potential interactions that must be addressed to enable accurate and effective assessment of the consequences of soil erosion on rangelands.

\section{Methods}

\section{Site characteristics}

The site was located in a semiarid rangeland on the Santa Rita Experimental Range ( $\left.31^{\circ} 50^{\prime} \mathrm{N}, 110^{\circ} 50^{\prime} \mathrm{W}\right)$ $\sim 50 \mathrm{~km}$ south of Tucson, Arizona. The study plots were located on a Sandy Loam Upland (SLU) ecological site that occupy Holocene alluvial fan and fan terrace surfaces with $\leq 8 \%$ slopes, sandy loam soils to $\sim 15 \mathrm{~cm}$ depth, and 5-25\% gravel at the surface (Breckenfeld and Robinett 2003, NRCS 2003). The site was located $\sim 1100 \mathrm{~m}$ above mean sea level, which is near the low elevation limit of the desert grassland and above the desert shrub (McClaran 2003). Mean annual air temperature at this location is $\sim 16^{\circ} \mathrm{C}$, with daily maximum air temperatures exceeding $35^{\circ} \mathrm{C}$ in summer (McClaran et al. 2002). Long-term (1923-2003) average annual precipitation near the study plots is $\sim 350 \mathrm{~mm}$ and is bimodally distributed, with more than half of the total annual precipitation occurring during the summer monsoon (July-September), with drier fall and spring months separating the wetter winter (January-March) and summer months (Sheppard et al. 2002).

\section{Experimental design and treatments}

We used 12 study plots $(50 \times 50 \mathrm{~m})$ in three replicated blocks in a relatively undisturbed semiarid grassland. Each of the study plots was separated by $\sim 100 \mathrm{~m}$ of undisturbed vegetation, which was left intact throughout the study period. Herbaceous canopy cover prior to disturbance was roughly $60-80 \%$, with Lehmann lovegrass (Eragrostis lehmanniana) constituting the majority $(>90 \%)$ of the grass cover. Due to excessive grazing in the area in the late 1800s and early 1900s, Lehmann lovegrass was introduced to the site in the mid 1900s to help combat soil erosion, and has since become the dominant species (McClaran et al. 2002). Woody plant canopy cover was $\sim 10 \%$, with velvet mesquite (Prosopis velutina) constituting the majority of the shrub cover. Four of the 12 study plots were undisturbed and served as a control, while the others were randomly assigned to one of the following treatments: prescribed burn (B), livestock grazing $(G)$, and prescribed burn followed by livestock grazing (BG). The prescribed burn was conducted on 29 July 2005 and was characterized as a light to moderate severity fire. The prescribed fire produced moderate soil heating at $1 \mathrm{~cm}\left(\sim 100^{\circ}-\right.$ $200^{\circ} \mathrm{C}$ ), charred or consumed most of the plant litter, partially consumed most woody debris except for logs, and had little to no visible effects on mineral soil and soil hydrophobicity. The livestock grazing treatment was characterized as short duration, moderate intensity, and was conducted from August to September 2005 by rotating approximately half a dozen cattle through each of the $50 \times 50 \mathrm{~m}$ study plots until roughly two-thirds of the herbaceous canopy cover was removed, which typically took about $7-10$ days per plot. The grazing treatment had little to no effect on herbaceous basal cover, nor on standing and fallen litter.

\section{Laboratory and field measurements}

Soil samples were collected from four locations within each of the nine plots at the end of the study period to avoid disturbing the plot surface. Soil cores $(5 \mathrm{~cm}$ diameter, $20 \mathrm{~cm}$ deep) were collected near each of the plot corners and aggregated into single composite samples for each of the nine study plots. Soil samples were oven dried at $60^{\circ} \mathrm{C}$ to constant mass. Particle size distribution was determined using the hydrometer method (Bouyoucos 1962). Vegetation canopy cover was measured within each plot using the line-point intercept method (Herrick et al. 2005) along two 50-m transects that extend the full length of the plots. Meteorological data were collected on site within a few hundred meters of the study plots. We obtained hourly averages of precipitation intensity (CS500-L, Campbell Scientific, Logan, Utah, USA) and wind speed and direction, measured at $3 \mathrm{~m}$ above the ground $(034 \mathrm{~B}$ wind sensor, Met One Instruments, Grants Pass, Oregon, USA).

Each of the study plots was instrumented with a series of Big Spring Number Eight (BSNE) samplers (Custom Products, Big Spring, Texas, USA) at five heights aboveground $(0.08,0.17,0.25,0.50$, and $1.0 \mathrm{~m})$ and a pair of bordered and unbordered sediment check dams to estimate wind- and water-driven sediment transport at the hillslope scale, respectively. Our measurements of wind-driven sediment transport are representative of local sediment transport or redistribution by wind at the field scale because BSNE samplers measure saltation (horizontal leaping of wind-blown particles from loca- 
tion of close proximity), not regional background dust (Fryrear 1986, Gillette et al. 1996). Both the BSNE samplers and the sediment check dams were located near the center of each plot, and both were estimated to have a capture efficiency of $\sim 90 \%$ (Fryrear 1986, Hastings et al. 2005). We used $3 \times 10 \mathrm{~m}$ bordered erosion plots to estimate water erosion at the hillslope scale, because they reflect the typical dimensions of a standard erosion plot for most rainfall simulation studies (e.g., Johansen et al. 2001). We also used unbordered erosion plots $(3 \mathrm{~m}$ wide perpendicular to slope) to estimate water-driven sediment transport. Our results for both wind- and water-driven sediment transport are normalized on a per-meter length basis to allow for direct comparisons between the two processes (Breshears et al. 2003). Sediment was collected from the BSNE samplers and check dams every $7-14$ days and oven dried at $60^{\circ} \mathrm{C}$ to constant mass. Sediment was collected from the BSNE samplers by thoroughly rinsing them with DI water and collecting the rinsate in $20-\mathrm{mL}$ glass vials.

\section{Data analysis}

Cumulative wind-driven sediment transport was calculated by integrating horizontal flux measurements from 0 to $1 \mathrm{~m}$ above the soil surface using an exponential relationship with height (Gillette et al. 1997, Stout 2001). We used a one-way ANOVA to test for significant differences $(P<0.05)$ in the mean values of wind- and water-driven sediment transport in burned, grazed, burned and grazed, and undisturbed plots. ANOVA was carried out according to the general linear model procedure of the Statistical Analysis System and Type III sums of squares using JMP 8.0 (SAS 2009). Results were considered significant at the $\alpha$ level of 0.05 . When significant differences among mean values were detected, Tukey's hsd (honestly significant difference) test was used to separate means.

\section{REsUlts}

\section{Climatic drivers and site characteristics}

Water-driven sediment transport was characterized by infrequent precipitation events that were associated primarily with convective thunderstorm activity during the monsoon season (July-September; Fig. 1a). Winddriven sediment transport, in contrast, was characterized by more consistent and frequent events. Wind events were driven by a combination of small but nontrivial events associated with normal background conditions, and larger but less frequent events associated with strong wind gusts induced by diurnal temperature fluctuations, as well as frontal and convective thunderstorms (Fig. 1b). Both types of sediment fluxes were influenced to a large extent by climate variation and extreme events. However, our results, which include a 25 -year precipitation event followed by the driest ninemonth period on instrumental record, suggest that vegetation cover can be the dominant factor controlling rates of wind- and water-driven sediment transport in

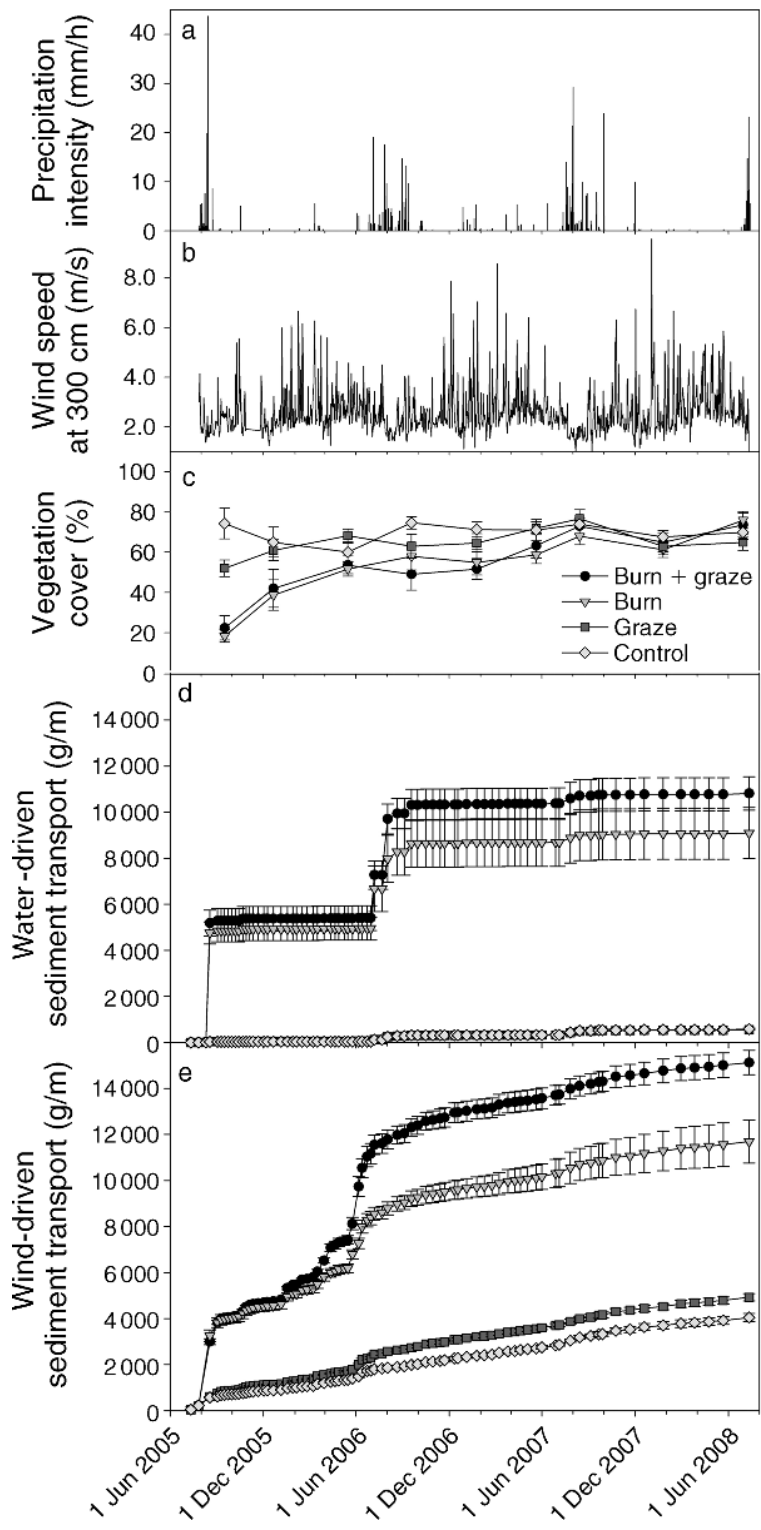

FIG. 1. Time series of (a) precipitation intensity, (b) average daily wind speed at $300 \mathrm{~cm}$, (c) percent vegetation cover, (d) water-driven sediment transport, and (e) wind-driven sediment transport following grazing, burning, and control treatment on a semiarid rangeland on the Santa Rita Experimental Range south of Tucson, Arizona, USA. Error bars represent \pm SE.

semiarid grasslands over time periods (i.e., years to decades) relevant to most range management practices (Field et al. 2009b:180-195).

Vegetation cover was reduced to $\sim 20 \%$ following the prescribed fire and remained low relative to unburned plots for about two years following the fire. In contrast, vegetation cover following livestock grazing was reduced to a lesser extent and for a shorter duration, primarily because the grazing treatment had little effect on basal cover and did not consume standing or fallen litter (Fig. 1c). Other surface site characteristics including soil 
texture, percentage of gravel, and bulk density did not change substantially following treatment or at the end of the three-year study period. Because grazing and burning were one-time treatments and of light to moderate intensity, their effect on soil properties were likely minimized, especially due to the rapid vegetation recovery that took place following the unusually wet period in August and September 2005. Soils at the site were predominantly sandy loam (sand $=68 \% \pm 11 \%$, silt $=19 \% \pm 6 \%$, clay $=13 \% \pm 5 \%$; mean \pm SD), with $\sim 10-$ $15 \%$ gravel at the surface and an average bulk density of $1.58 \pm 0.11 \mathrm{Mg} / \mathrm{m}^{3}$. Slopes at the site ranged from $\sim 5-$ $8 \%$, and with the exception of gravel, had few nonerodible surface elements and little or no biological or physical soil crusts.

\section{Effects of burning and grazing}

Although the first year following treatment was characterized by extreme wet/dry events, the lack of vegetation cover in the burned plots appeared to be the dominant factor driving the large increases in wind- and water-driven sediment transport observed during year 1 of the study, because control plots had more consistent annual rates of sediment transport throughout the threeyear study period (Fig. 1d, e). For all treatments (i.e., grazed, burned, burned + grazed), the cumulative amount of wind-driven sediment transport exceeded that of water due to a combination of ongoing small but nontrivial wind events, as well as larger but less frequent wind events that generally preceded frontal and convective thunderstorms. In fact, the small but nontrivial background wind events from July 2006 to the end of the study are what led to the differences between wind- and water-driven sediment transport in the burned and burned + grazed treatments.

Grazing and burning had differential effects on the relative rates of wind- and water-driven sediment transport. Mean wind-driven sediment transport for the first year of the study in the grazed plots $(5.96 \pm 0.32$ $\left.\mathrm{g} \cdot \mathrm{m}^{-1} \cdot \mathrm{d}^{-1}\right)$ was elevated by $>30 \%$ relative to the control plots $\left(4.50 \pm 0.34 \mathrm{~g} \cdot \mathrm{m}^{-1} \cdot \mathrm{d}^{-1}\right.$; Fig. 2a, b), although this difference was not statistically significant. The relative difference between the grazing and control treatments increased during the second year of the study, with wind-driven sediment transport in the grazed plots $(4.29$ $\left.\pm 0.34 \mathrm{~g} \cdot \mathrm{m}^{-1} \cdot \mathrm{d}^{-1}\right)$ nearly $40 \%$ greater than that in the control plots $\left(3.10 \pm 0.20 \mathrm{~g} \cdot \mathrm{m}^{-1} \cdot \mathrm{d}^{-1}\right)$. The prescribed fire significantly increased rates of wind- and water-driven sediment transport during the first two years following treatment; however, the effect of fire increased waterdriven sediment transport to a much greater extent than wind-driven sediment transport (Fig. 2c, d). The combination of burning and grazing had a synergistic effect that resulted in a significant increase in wind-driven sediment transport, but this effect was only observed during the second year of the study and only in the case of wind-driven sediment transport. Burning and grazing had no effect on wind-driven sediment transport in the third year of the study; however, rates of water-driven sediment transport were still slightly elevated three years following the fire, although still substantially less than rates of wind-driven sediment transport during the third year of the study (Fig. 2e, f).

\section{Wind: water sediment transport ratio}

Notably, the wind: water sediment transport ratio decreased following burning but increased or remained relatively unchanged compared to the control following grazing (Fig. 3). Although the prescribed fire significantly increased rates of water-driven sediment transport relative to that of wind, the wind: water sediment transport ratio was still positive (i.e., wind-driven sediment transport $>$ water-driven sediment transport) during the first year following treatment (Fig. 3a). In the second year of the study, which was characterized by near normal amounts of annual precipitation, waterdriven sediment transport actually exceeded that of wind in the burned plots, causing a rapid shift in the dominant form of sediment flux (Fig. 3b). For the unburned plots, the wind: water sediment transport ratio was significantly greater in the grazed treatment $(5.25 \pm 0.24)$ than the control $(3.87 \pm 0.86)$, but only during the second year of the study. Although the magnitudes of the wind: water sediment transport ratios were similar for all treatments three years following disturbance, significant differences were still observed between the burned and control plots, indicating possible residual effects of burning on soil erosion up to three years following light- to moderate-severity rangeland fires (Fig. 3c).

\section{Discussion}

\section{Effects of rangeland practices on sediment fluxes}

Wind and water erosion and transport are thought to be co-occurring processes in many drylands, and potentially interrelated under a wide range of spatial and temporal scales (Schumm 1965, Marshall 1973, Kirkby 1978, Bullard and McTainsh 2003), yet surprisingly little information is available on the absolute and relative magnitudes of wind- and water-driven sediment fluxes, particularly following rangeland practices. Our co-located measurements of wind- and water-driven sediment transport indicate that both types of sediment fluxes could potentially contribute substantially to total erosion in many semiarid rangelands. Notably, our fieldbased measurements of both processes indicate that even in semiarid rangelands with substantial ground cover and seasonally intense thunderstorm activity, winddriven sediment transport can be a substantial component of the total through small, persistent events. Our study suggests, in addition to others, that simultaneous measurements of coupled aeolian and fluvial processes are necessary to better assess soil erosion and sediment fluxes in drylands (Bullard and Livingstone 2002, Visser et al. 2004, Field et al. 2009a), as well as their associated feedbacks on land use and climate change. Although the first year following treatment was characterized by wet/ 

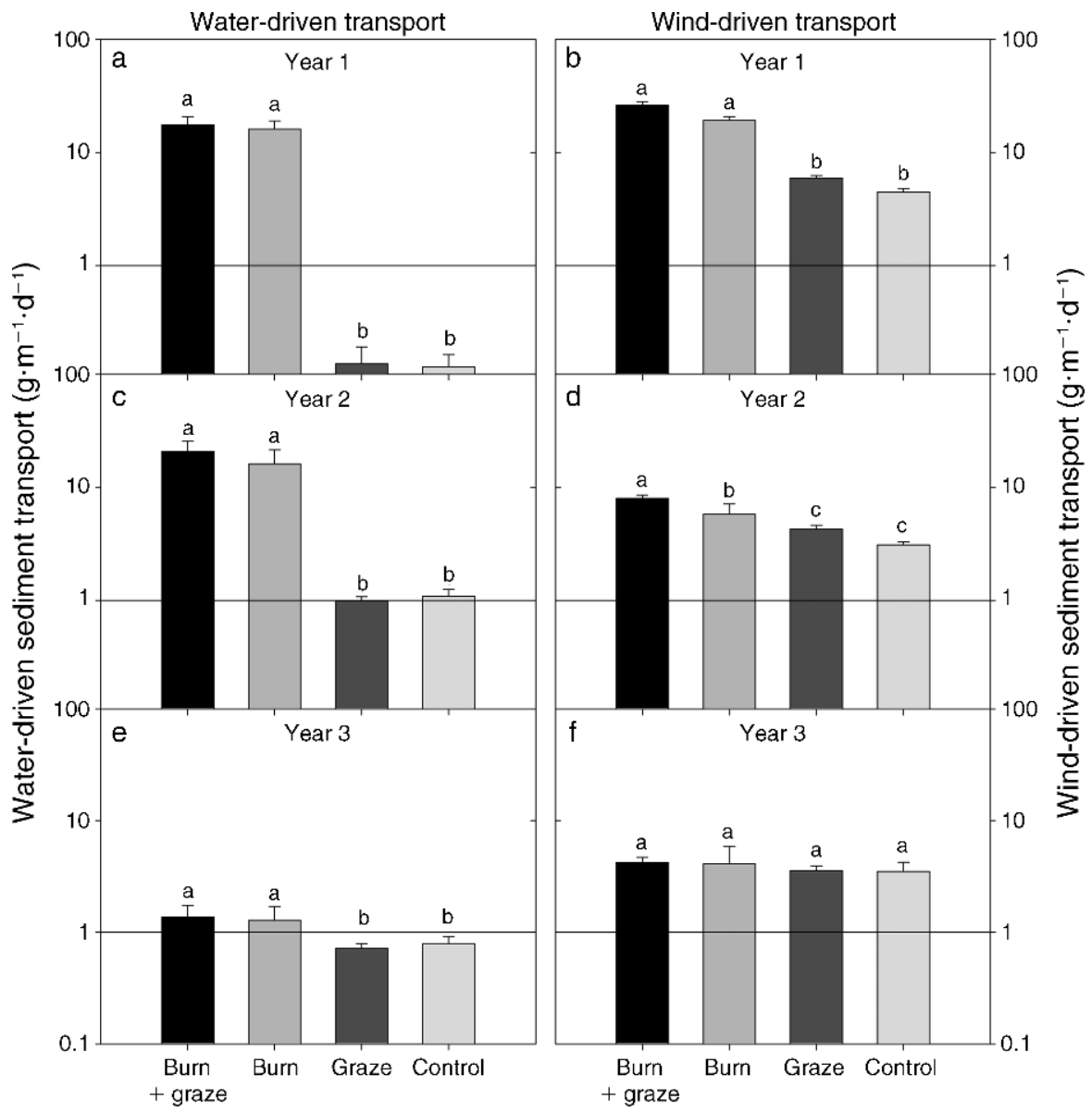

FIG. 2. Annual rates of wind- and water-driven sediment transport in a semiarid rangeland following grazing and burning for (a, b) the first, (c, d) second, and (e,f) third year of treatment. Note that the $y$-axis is plotted on a logarithmic scale. Error bars represent the standard error of the mean; means for a given vector (wind or water) for a given year with the same letter do not differ significantly (Tukey's hsd test; $P<0.05$ ).

dry extremes, the lack of vegetation cover in the burned plots appears to be the dominant factor driving the large increases in sediment fluxes by both wind and water that were observed during the first year of the study. For all treatments, cumulative wind-driven sediment fluxes exceeded that of water due to a combination of nontrivial ongoing background rates and elevated rates that preceded thunderstorm activity associated with the monsoons.

Range management practices such as grazing and prescribed fire can have differential effects on the wind: water sediment transport ratio, likely due to changes in the height and percent canopy cover of herbaceous vegetation. Although rates of wind- and water-driven sediment transport exhibited varied responses to grazing and burning, overall trends among treatments were consistent between both types of sediment fluxes: burned + grazed $>$ burned $\gg$ grazed $\geq$ control, with effects immediately apparent after burning, but delayed after grazing until the following growing season. Many studies have reported increases in either wind- or water-driven sediment fluxes following grazing and burning, but essentially no field measurements are available for both processes at the same location following either type of disturbance (Visser et al. 2004).

In this study we found that the wind: water sediment transport ratio increased following grazing but substantially decreased following burning. We hypothesize that this varied response in the wind:water sediment transport ratio following grazing and burning could potentially be at least partially explained by changes in the height and percent canopy cover of herbaceous vegetation. Livestock grazing practices often result in a dramatic reduction in the height and percent canopy cover of herbaceous vegetation (Sala et al. 1986, Holling 1992, Adler et al. 2001), both of which can have substantial effects on aeolian sediment transport through changes in near-surface wind speeds and turbulence, as well as the degree of spatial connectivity (Raupach et al. 1993, Wolfe and Nickling 1993, Vermeire et al. 2005, Breshears et al. 2009, Okin et al. 


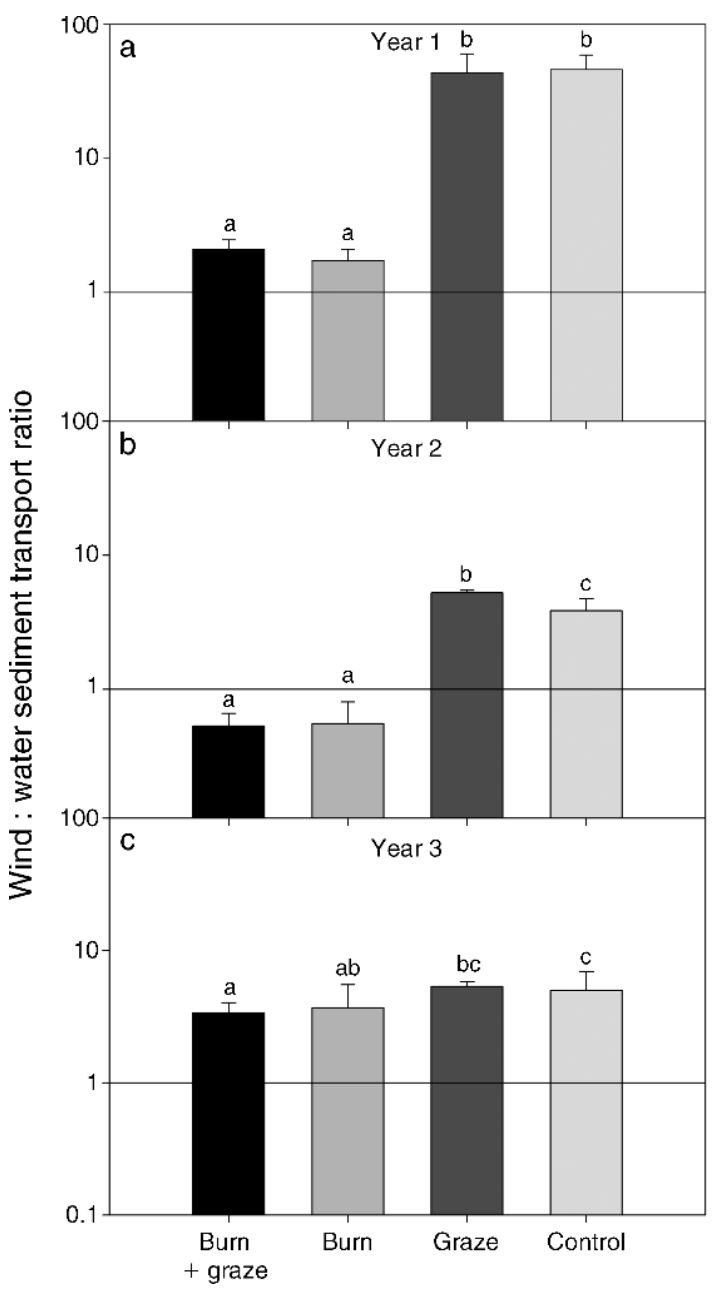

FIG. 3. Wind: water sediment transport ratio in a semiarid grassland following grazing and burning for (a) the first, (b) second, and (c) third year of treatment. Note that the $y$-axis is plotted on a logarithmic scale. Error bars represent the standard error of the mean; means with the same letter do not differ significantly (Tukey's hsd test; $P<0.05$ ).

2009; Fig. 4). Most livestock grazing practices, however, typically do not result in a dramatic reduction in the amount of herbaceous basal cover (Williams 1968, Sala et al. 1986, Virgona and Bowcher 2000). Basal cover can serve as an important barrier to water-driven sediment transport because fluvial processes operate primarily on the soil surface. Aeolian transport processes, however, are much more three dimensional and less likely to be influenced by herbaceous basal cover due to the jumping or leaping motion of saltating particles (Fig. 4). Range management practices that result in the reduction or removal of herbaceous basal cover, such as prescribed burning, can result in a disproportionate increase in water-driven sediment transport relative to that of wind. Although further investigation is required to better understand the mechanisms driving this response, we hypothesize that the fast recovery of herbaceous canopy cover $(\sim 3$ months $)$ in locations where perennial bunchgrasses survived the fire resulted in sufficient resistance to the wind flow to reduce the potential for aeolian sediment transport. The fast recovery of herbaceous canopy cover, however, had little effect on overland flow and fluvial sediment transport (Fig. 4). It appears that the amount of herbaceous basal cover remaining after the fire was insufficient to reduce the potential for fluvial sediment transport, likely because an erosion threshold was reached in response to the large increase in spatial connectivity among bare patches after the fire. Studies have suggested that there appears to be a threshold-like response for fluvial sediment transport when the amount of soil exposed by fire increases above $\sim 60-70 \%$ (e.g., Johansen et al. 2001), as was the case in this study. Although there might be a similar threshold-like response for aeolian sediment transport following fire, the point at which this might occur is unclear due to the relatively small number of studies that have quantified aeolian sediment transport rates following such disturbance in nonagricultural systems such as grasslands, shrublands, and woodlands (Breshears et al. 2009).

Our findings suggest that aeolian transport processes may be more sensitive than fluvial processes to the removal of herbaceous canopy cover, assuming basal cover remains intact. The apparent sensitivity of aeolian transport processes to herbaceous canopy cover could help explain why the grazing treatment following the prescribed fire resulted in a significant increase in winddriven sediment transport but had little or no effect on water-driven sediment transport. Based on our colocated measurements, wind-driven sediment transport can be a substantial fraction of the total sediment flux in semiarid rangelands and potentially many other types of dryland ecosystems (Schumm 1965, Breshears et al. 2003, Bullard and McTainsh 2003, Visser et al. 2004). In addition, our results indicate that the influence of land management practices on the absolute and relative magnitudes of wind- and water-driven sediment transport can have important implications for sustainable management of rangelands and should be considered as a critical part of any range management plan (Thurow and Taylor 1999, Holechek et al. 2001, Emmerich and Heitschmidt 2002).

\section{Implications for rangeland management and vegetation-soil dynamics}

Long-term rangeland sustainability depends in large part on maintaining adequate soil quality and health. In many cases the difference between long-term rangeland sustainability and degradation can be dependent on maintaining surface stability and adequate soil quality and health. This often involves reducing the potential for soil erosion by maintaining adequate vegetation cover to protect the soil surface from the erosive forces of wind and water, particularly following range management practices, such as grazing and burning. 


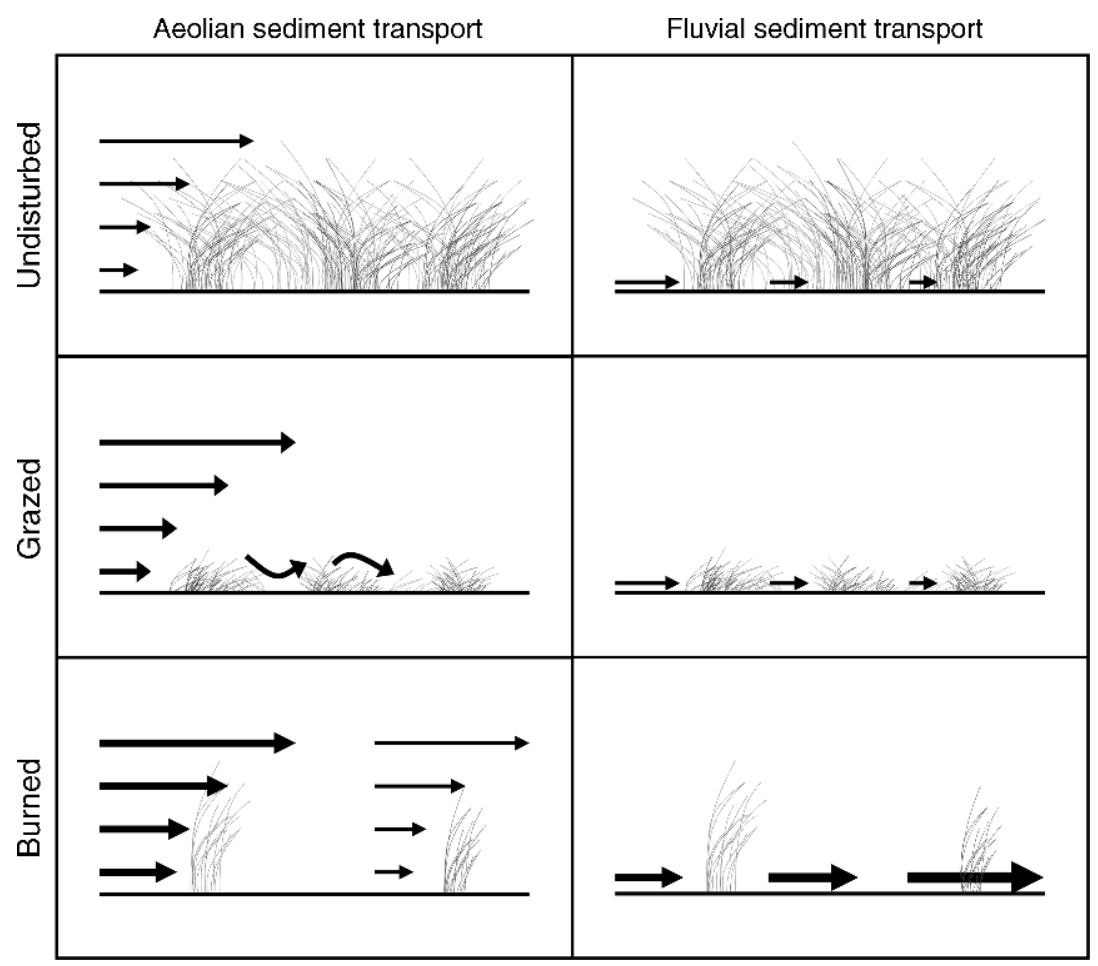

FIG. 4. A conceptual model of the effects of grazing and burning on vegetation structure and on resultant vectors of aeolian and fluvial sediment transport. The length of arrows represents spatial connectivity among bare patches; the width of arrows represents potential sediment transport capacity. For undisturbed rangelands, spatial connectivity and sediment transport capacity are relatively small for both wind and water. In grazed systems, herbaceous canopy cover is reduced, resulting in increased turbulence and sediment transport capacity for wind but not for water. In burned systems, most cover is consumed by fire, resulting in a threshold-like response for fluvial but not aeolian sediment transport, likely because herbaceous basal cover after the fire was insufficient to reduce the potential for overland flow, but herbaceous canopy cover appeared somewhat effective at reducing wind speeds and near-ground turbulence.

Sustainable rangeland management depends primarily on alternate grazing and burning practices to control large-scale manipulations of vegetation type and cover. Holistic assessment of rangeland health and soil quality is impeded partly by lack of awareness and knowledge about the combined effects of wind and water erosion and transport in managed landscapes. Due to the lack of co-located measurements of wind and water erosion and transport, it is difficult to assess the relative importance of wind- and water-driven sediment fluxes, particularly following disturbances such as grazing and burning.

Our co-located measurements of wind- and waterdriven sediment transport indicate that sediment fluxes driven by wind exceeded that of water for most treatments and most years. Grazing appears to increase the wind: water sediment transport ratio, whereas burning can result in a substantial decrease in the ratio. Changes in wind- and water-driven sediment fluxes in response to land management practices such as prescribed fire and grazing could have important implications for rangeland sustainability and degradation. For example, our measurements of wind-driven sediment transport suggest that the effects of livestock grazing on wind erosion may not be fully apparent until the beginning of the following growing season, which could have important implications for managing livestock stocking rates on rangelands. Further, rangelands that might be particularly susceptible to wind erosion due to a combination of factors such as high aridity, strong winds, and coarse-textured soils should also be managed more carefully with respect to livestock stocking rates to avoid potential increased dust emissions. In contrast, rangelands that might be particularly susceptible to water erosion due to a combination of factors such as high rainfall intensity, steep slopes, and fine-textured soils should be managed more carefully with respect to the timing and the intensity of prescribed fires to reduce the potential for accelerated rates of water erosion.

Range management practices that cause a substantial change in the absolute and relative magnitudes of wind and water erosion and transport could have important ecological implications for vegetation patch structure and dynamics, as well as the structure and functioning of dryland ecosystems (Aguiar and Sala 1999, Michaelides et al. 2009, Ravi et al. 2010). Our results show that rangeland practices differentially alter sediment fluxes driven by wind and water, differences that could potentially help explain divergence between rangeland 
sustainability and degradation. In conclusion, our results highlight the pressing need for more simultaneous field measurements of sediment fluxes driven by both wind and water to better assess rangeland health and the overall environmental and economic impacts of soil erosion to guide best management practices.

\section{ACKNOWLEDGMENTS}

We thank Chris McDonald and Guy McPherson for establishing the treatments and experiment design. This study was supported by the Arizona Agricultural Experiment Station (DDB), the U.S. Department of Agriculture Cooperative State Research, Education, and Extension Service (D. D. Breshears, J. P. Field; CSREES 2005-38420-15809), the National Science Foundation (J. P. Field, D. D. Breshears; NSF-DEB 0816162), and the Department of Energy (J. J. Whicker; DE-AC5206NA25396).

\section{Literature Cited}

Adler, P. B., D. A. Raff, and W. K. Lauenroth. 2001. The effect of grazing on the spatial heterogeneity of vegetation. Oecologia 128:465-479.

Aguiar, M. R., and O. E. Sala. 1999. Patch structure, dynamics and implications for the functioning of arid ecosystems. Trends in Ecology and Evolution 14:273-277.

Alfaro, S. C., and L. Gomes. 2001. Modeling mineral aerosol production by wind erosion: emission intensities and aerosol size distributions in source areas. Journal of Geophysical Research 106:18075-18084.

Belnap, J. 1995. Surface disturbances: their role in accelerating desertification. Environmental Monitoring and Assessment 37:39-57.

Belnap, J., R. L. Reynolds, M. C. Reheis, S. L. Phillips, F. E. Urban, and H. L. Goldstein. 2009. Sediment losses and gains across a gradient of livestock grazing and plant invasion in a cool semi-arid grassland, Colorado Plateau, USA. Aeolian Research 1:27-43.

Bennett, H. H., and W. R. Chapline. 1928. Soil erosion: a national menace. USDA Circular 33, United States Department of Agriculture, Washington, D.C., USA.

Bochet, E., J. Poesen, and J. L. Rubio. 2000. Mound development as an interaction of individual plants with soil, water erosion and sedimentation processes on slopes. Earth Surface Processes and Landforms 25:847-867.

Bouyoucos, G. J. 1962. Hydrometer method improved for making particle size analyses of soils. Agronomy Journal 54 464-465.

Breckenfeld, D. J., and D. Robinett. 2003. Soil and ecological sites on the Santa Rita Experimental Range. Pages 157-165 in M. P. McClaran, P. F. Ffolliott, and C. B. Edminster, technical coordinators. Santa Rita Experimental Range: 100 years (1903-2003) of accomplishments and contributions; Conference Proceedings, 30 October-12 November 2002 USDA Forest Service Rocky Mountain Research Station Proceedings RMRS-P-30, Tucson, Arizona, USA.

Breshears, D. D., J. J. Whicker, M. P. Johansen, and J. E. Pinder. 2003. Wind and water erosion and transport in semiarid shrubland, grassland and forest ecosystems: quantifying dominance of horizontal wind-drive transport. Earth Surface Processes and Landforms 28:1189-1209.

Breshears, D. D., J. J. Whicker, C. B. Zou, J. P. Field, and C. D. Allen. 2009. A conceptual framework for dryland aeolian sediment transport along the grassland-forest continuum: effects of woody plant canopy cover and disturbance. Geomorphology 105:28-38.

Bullard, J. E., and I. Livingstone. 2002. Interactions between aeolian and fluvial systems in dryland environments. Area 34: $8-16$.

Bullard, J. E., and G. H. McTainsh. 2003. Aeolian-fluvial interactions in dryland environments: examples, concepts and
Australia case study. Progress in Physical Geography 27:471501

Chartier, M. P., C. M. Rostagno, and F. A. Roig. 2009. Soil erosion rates in rangelands of northeastern Patagonia: a dendrogeomorphological analysis using exposed shrub roots. Geomorphology 106:344-351.

Costanza, R., et al. 1997. The value of the world's ecosystem services and natural capital. Nature 387:253-260.

DeBano, L. F., D. G. Neary, and P. F. Ffolliot. 1998. Fire's effects of ecosystems. John Wiley and Sons, Hoboken, New Jersey, USA.

Dregne, H. E. 1983. Desertification of arid lands. Harwood Academic, New York, New York, USA.

Dunkerley, D. 2002. Systematic variation of soil infiltration rates within and between the components of the vegetation mosaic in an Australian desert landscape. Hydrological Processes 16:119-131.

Emmerich, W. E., and R. K. Heitschmidt. 2002. Drought and grazing: II. Effects on runoff and water quality. Journal of Range Management 55:229-234.

Field, J. P., D. D. Breshears, and J. J. Whicker. 2009a. Toward a more holistic perspective of soil erosion: why aeolian research needs to explicitly consider fluvial processes and interactions. Aeolian Research 1:9-17.

Field, J. P. 2009b. Differential response of wind and water erosion under climatic extremes and alternate land management practices. Ph.D. dissertation. School of Natural Resources and the Environment, University of Arizona, Tucson, Arizona, USA.

Fryrear, D. W. 1986. A field dust sampler. Journal of Soil and Water Conservation 41:117-120.

Gillette, D. A. 1977. Fine particle emissions due to wind erosion. Transactions of the American Society of Agricultural Engineers 20:890-897.

Gillette, D. A., D. W. Fryrear, T. E. Gill, T. Ley, T. A. Cahill, and E. A. Gearhart. 1997. Relation of vertical flux of particles smaller than $10 \mu \mathrm{m}$ to total aeolian horizontal mass flux at Owens Lake. Journal of Geophysical Research 102: 26009-26015.

Gillette, D. A., G. Herbert, P. H. Stockton, and P. R. Owen. 1996. Causes of the fetch effect in wind erosion. Earth Surface Processes and Landforms 21:641-659.

Greiner, R., I. Gordon, and C. Cocklin. 2009. Ecosystem services from tropical savannas: economic opportunities through payments for environmental services. Rangeland Journal 31:51-59.

Hastings, B. K., D. D. Breshears, and F. M. Smith. 2005. Spatial variability in rainfall erosivity versus rainfall depth: Implications for sediment yield. Vadose Zone Journal 4:500 504

Havstad, K. M., D. P. C. Peters, R. Skaggs, J. Brown, B. Bestelmeyer, E. Fredrickson, J. Herrick, and J. Wright. 2007. Ecological services to and from rangelands of the United States. Ecological Economics 64:261-268.

Herrick, J. E., J. W. Van Zee, K. M. Havstad, L. M. Burkett, and W. G. Whitford. 2005. Monitoring manual for grassland, shrubland and savanna ecosystems. Volume I. Quick start. University of Arizona Press, Tucson, Arizona, USA.

Holechek, J. L., R. D. Pieper, and C. H. Herbel. 2001. Range management principles and practices. Fourth edition. Prentice Hall, Upper Saddle River, New Jersey, USA.

Holling, C. S. 1992. Cross-scale morphology, geometry, and dynamics of ecosystems. Ecological Monographs 62:447-502.

Johansen, M. P., T. E. Hakonson, and D. D. Breshears. 2001. Post-fire runoff and erosion from rainfall simulation: contrasting forests with shrublands and grasslands. Hydrological Processes 15:2953-2965.

Kirkby, M. J. 1978. The stream head as a significant geomorphic threshold. Department of Geography, University of Leeds Working Paper, Leeds, UK. 
Lal, R., T. M. Sobecki, T. Iivari, and J. M. Kimble. 2003. Soil degradation in the United States: extent, severity, and trends. Lewis Publication, Boca Raton, Florida, USA.

Larson, W. E., F. J. Pierce, and R. H. Dowdy. 1983. The threat of soil-erosion to long-term crop production. Science 219: $458-465$.

Marshall, J. K. 1973. Drought, land use and soil erosion. Pages 55-77 in J. V. Lovett, editor. The environmental economic and social significance of drought. Angus and Robertson, Sydney, Australia.

McClaran, M. P. 2003. A century of vegetation change on the Santa Rita Experimental Range. In M. P. McClaran, P. F. Ffolliott, and C. B. Edminster, technical coordinators. Santa Rita Experimental Range: 100 years (1903-2003) of accomplishments and contributions; Conference Proceedings, 30 October-12 November 2002. USDA Forest Service Rocky Mountain Research Station Proceedings RMRS-P-30, Tucson, Arizona, USA.

McClaran, M. P., D. L. Angell, and C. Wissler. 2002. Santa Rita Experimental Range digital database: user's guide. USDA Forest Service Rocky Mountain Experiment Station General Technical Report RM GTR-100.

Michaelides, K., D. Lister, J. Wainwright, and A. J. Parsons. 2009. Vegetation controls on small-scale runoff and erosion dynamics in a degrading dryland environment. Hydrological Processes 23:1617-1630.

Millennium Ecosystem Assessment. 2005. Ecosystems and human well-being: desertification synthesis. World Resources Institute, Washington, D.C., USA.

Moss, A. J., and P. H. Walker. 1978. Particle transport by continental water flows in relation to erosion, deposition, soils, and human activities. Sedimentary Geology 20:81-139.

Nash, M. S., E. Jackson, and W. G. Whitford. 2004. Effects of intense, short-duration grazing on microtopography in a Chihuahuan Desert grassland. Journal of Arid Environments 56:383-393.

Neff, J. C., A. P. Ballantyne, G. L. Famer, N. M. Mahowald, J. L. Conroy, C. C. Landry, J. T. Overpeck, T. H. Painter, C. R. Lawrence, and R. L. Reynolds. 2008. Increasing eolian dust deposition in the western United States linked to human activity. Nature Geoscience 1:189-195.

Noy-Meir, I. 1973. Desert ecosystems: environment and producers. Annual Review of Ecology and Systematics 4: $25-51$.

NRCS (Natural Resources Conservation Service). 2003. Ecological site information system descriptions. U.S. Department of Agriculture, Washington, D.C., USA. 〈http://esis.sc. egov.usda.gov

Okin, G. S., A. J. Parsons, J. Wainwright, J. E. Herrick, B. T. Bestelmeyer, D. C. Peters, and E. L. Fredrickson. 2009. Do changes in connectivity explain desertification? BioScience 59:237-244

Parsons, A. J., A. D. Abrahams, and J. R. Simanton. 1992. Microtopography and soil-surface materials on semi-arid piedmont hillslopes, southern Arizona. Journal of Arid Environments 22:107-115.

Pillans, B. 1997. Soil development at snail's pace: evidence from a 6 Ma soil chronosequence on basalt in north Queensland, Australia. Geoderma 80:117-128.

Pimentel, D., and N. Kounang. 1998. Ecology of soil erosion in ecosystems. Ecosystems 1:416-426.

Raupach, M. R., D. A. Gillette, and J. F. Leys. 1993. The effect of roughness elements on wind erosion threshold. Journal of Geophysical Research-Atmospheres 98:3023-3029.

Ravi, S., D. D. Breshears, T. E. Huxman, and P. D'Odorico. 2010. Land degradation in drylands: interactions among hydrologic-aeolian erosion and vegetation dynamics. Geomorphology 116:236-245.

Ravi, S., P. D'Odorico, B. Herbert, T. M. Zobeck, and T. M. Over. 2006. Enhancement of wind erosion by fire-induced water repellency. Water Resources Research 42:W11422.
Ravi, S., P. D’Odorico, L. Wang, C. S. White, G. S. Okin, S. A. Macko, and S. L. Collins. 2009. Post-fire resource redistribution in desert grasslands: a possible negative feedback on land degradation. Ecosystems 12:434-444.

Ravi, S., P. D’Odorico, T. M. Zobeck, T. M. Over, and S. L. Collins. 2007. Feedbacks between fires and wind erosion in heterogeneous arid lands. Journal of Geophysical Research-Biogeosciences 112:G04007.

Rostagno, C. M., H. F. del Valle, and L. Videla. 1988. Mounds associated with shrubs in aridic soils of North-eastern Patagonia: characteristics and probable genesis. Catena 15: 347-359.

Sala, O. E., M. Oesterheld, R. J. C. Leon, and A. Soriano. 1986. Grazing effects upon plant community structure in subhumid grasslands of Argentina. Vegetatio 67:27-32.

Sampson, A. W., and L. H. Weyl. 1918. Range preservation and its relation to erosion control on Western grazing lands. USDA Bulletin 675, United States Department of Agriculture, Washington, D.C., USA.

SAS. 2009. Program JMP 8.0. SAS, Cary, North Carolina, USA.

Schlesinger, W. H., J. F. Reynolds, G. L. Cunningham, L. F. Huenneke, W. M. Jarrell, R. A. Virginia, and W. G. Whitford. 1990. Biological feedbacks in global desertification. Science 247:1043-1048.

Schoch, P., and D. Binkley. 1986. Prescribed burning increased nitrogen availability in a mature loblolly pine stand. Forest Ecology and Management 14:13-22.

Schumm, S. A. 1965. Quaternary paleohydrology. Pages $783-$ 794 in H. E. Wright, Jr. and D. G. Frey, editors. The Quaternary of the United States. A Review Volume for the VII Congress of the International Union for Quaternary Research, Princeton, New Jersey, USA.

Shao, Y., M. R. Raupach, and J. F. Leys. 1996. A model for predicting aeolian sand drift and dust entrainment on scales from paddock to region. Australian Journal of Soil Research 34:309-342.

Sheppard, P. R., A. C. Comrie, G. D. Packin, K. Augersbach, and M. K. Hughes. 2002. The climate of the US Southwest. Climate Research 21:219-238.

Stevens, P. R., and T. W. Walker. 1970. Chronosequence concept and soil formation. Quarterly Review of Biology 45: $333-350$.

Stout, J. E. 2001. Dust and environment in the Southern High Plains of North America. Journal of Arid Environments 47: 425-441.

Thurow, T. L., and C. A. Taylor. 1999. Viewpoint: the role of drought in range management. Journal of Range Management 52:413-419.

Trimble, S. W., and A. C. Mendel. 1995. The cow as a geomorphic agent - a critical review. Geomorphology 13: 233-253.

Turnbull, L., J. Wainwright, and R. E. Brazier. 2008. A conceptual framework for understanding semi-arid land degradation: ecohydrological interactions across multiplespace and time scales. Ecohydrology 1:23-34.

Vermeire, L. T., D. B. Wester, R. B. Mitchell, and S. D. Fuhlendorf. 2005. Fire and grazing effects on wind erosion, soil water content, and soil temperature. Journal of Environmental Quality 34:1559-1565.

Virgona, J. M., and A. Bowcher. 2000. Effects of grazing interval on basal cover of four perennial grasses in a summerdry environment. Australian Journal of Experimental Agriculture 40:299-311.

Visser, S. M., G. Sterk, and O. Ribolzi. 2004. Techniques for simultaneous quantification of wind and water erosion in semi-arid regions. Journal of Arid Environments 59:699-717.

Weaver, J. E., and W. M. Noll. 1935. Measurement of runoff and soil erosion by a single investor. Ecology 16:1-13.

Weltz, A. M., G. Dunn, J. Reeder, and G. Frasier. 2003. Ecological sustainability of rangelands. Arid Land Research and Management 17:369-388. 
Whicker, J. J., D. D. Breshears, P. T. Wasiolek, T. B. Kirchner, R. A. Tavani, D. A. Schoep, and J. C. Rodgers. 2002. Temporal and spatial variation of episodic wind erosion in unburned and burned semiarid shrubland. Journal of Environmental Quality 31:599-612.

Wilcox, B. P., D. D. Breshears, and C. D. Allen. 2003 Ecohydrology of a resource-conserving semiarid woodland: effects of scale and disturbance. Ecological Monographs 73: 223-239.

Williams, O. B. 1968. Studies in the ecology of the Riverine Plain. IV. Basal area and density changes of Danthonia caespitosa Gaudich, in a natural pasture grazed by sheep. Australian Journal of Botany 16:565-578.

Wolfe, S. A., and W. G. Nickling. 1993. The protective role of sparse vegetation in wind erosion. Progress in Physical Geography 17:50-68.

Zobeck, T. M., G. Sterk, R. Funk, J. L. Rajot, J. E. Stout, and R. S. Van Pelt. 2003. Measurement and data analysis methods for field-scale wind erosion studies and model validation. Earth Surface Processes and Landforms 28:11631188 . 